\title{
Making the leap into entrepreneurship
}

\author{
Randall Schatzman, Mark Litton, John Latham \& Jeffrey Smith \\ Job security in big pharma is not what it once was. For those looking for a new challenge, a group of big company \\ refugees recount their experience starting up a new life science venture.
}

\begin{abstract}
Recent years have witnessed numerous layRoffs in R\&D teams at drug developers and especially in big pharma. According to consulting firm Challenger, Gray \& Christmas in Chicago, the pharma industry shed 37,265 jobs in the first 8 months of this year compared with 53,004 jobs in all of last year. These cutbacks have left many talented researchers considering next steps, whether seeking employment with another major drug developer, looking to move to a smaller biotech or even creating and running a new venture.
\end{abstract}

If you're looking to move on-whether by design or circumstance-and the last option had not occurred to you, it's worth careful consideration. One advantage of creating a new company is that you will be your own boss and you'll be pursuing research in an area that you are passionate about. On the other hand, creating a biotech company from the ground takes years of drive and devotion. But with the right attitude and advice along the way, such an endeavor can bring both personal satisfaction and financial return.

Before you even consider this path, though, it is important to understand that the environment associated with building a startup company is very different from that of a major drug developer. There is a great lack of security that you must be able to overcome if you choose the path of creating a startup. As a first-time founder of a startup has commented to us: "It's like nothing you've experienced in your job at big pharma."

\section{Nurtured from a napkin}

For us, it all began on the back of a paper napkin in a local microbrewery outside Seattle.

Randall Schatzman is president and CEO, Mark Litton is chief business officer, John Latham is CSO and Jeffrey Smith is chief medical officer at Alder Biopharmaceuticals, Bothell, Washington, USA.

e-mail:info@alderbio.com
The four of us had been given notice from Celltech in Bothell, Wash., where we'd worked in the research facility. We were contemplating our next steps, such as who was hiring or where we might find work. It might have been the beverage, but by the end of lunch we were convinced that there was a better way to discover and produce antibodies, and the answer was through yeast. We began thinking about starting our own company.

We were well aware of the complexities of developing biotherapeutics through our work at Celltech, but we believed we could move more quickly as a small organization. This realization might be the same one other people experience when they're considering starting their own companies-today, more than ever, there is a need for smaller, nimble organizations.

This need for speed and focus influenced the decision to create Alder as a small organization with everyone kept close to the strategy. This led to a hard-to-define internal buzz that you don't find in large corporations, and it drove our team to work harder and faster. In small companies everyone has, in the back of their mind, the knowledge that there is a cliff close by; it's invigorating to know you may head over the edge at any point. This isn't an ideal situation for everyone, but if it works for you, you'll find it to be exciting and even energizing. It can certainly drive focus and motivation. It did for us, and it was especially refreshing after working in a bigger organization for so long.

\section{Focus on proving value}

After deciding to forgo the pharma life and start a new company, the next question is always where the focus should lie. Obviously, there is no 'one size fits all' answer for this, but the niche must fit the passion and experiences of the founder(s). In addition, it is important to find an area of research that can bring value quickly and yet still fulfill an important previously unmet need. Investors are typically interested in obtaining a return within a few years, so demonstrating that you are on track early is necessary. An unmet need is an opportunity, because as a startup you can prove yourself by actively pursuing goals that can bring solutions to larger companies' pipelines.

For Alder, the idea for our technology came from a challenge faced by antibody developers during the transition from research to the clinic. A big issue for most antibody programs occurs in manufacturing, as antibody protein levels are very low and not suitable for commercial production. This means considerable amounts of time are spent looking for sequences that express well in mammalian cells, which delays the development process. Mammalian cell culture tanks are also limited in terms of availability and size, creating long lead times because tanks need to be booked months in advance at extreme cost. Then manufacturing the antibodies themselves takes months before the final product is available for release.

This situation was especially noticeable when a Seattle company launched a great new therapeutic but was unable to manufacture large enough quantities to meet the patient demand. As a result, patients ended up in lotteries to receive the drug.

Alder's solution was to come up with a faster, more efficient way to make large proteins, specifically full-length monoclonal antibodies. This was when we turned to yeast-based cultures, which are fast enough to generate a commercial antibody strain in a few weeks and inexpensive enough to do so at a fraction of what it costs to produce mammalian cell cultures. We solved the problem using what at the time was a new expression system: the yeast Pichia pastoris. This technology, alongside a method of finding very 


\section{Box 1 Making our way}

To date, Alder has raised a total of $\$ 67$ million through venture capital. Alder closed a Series A round in July 2005, with Sevin Rosen Funds of Palo Alto, Calif., leading the $\$ 11$ million round, joined by Ventures West Management of Vancouver, Canada, and WRF Capital of Seattle. In July 2006, Alder closed its \$16 million Series B round with H.I.G. Ventures of Miami leading and being joined by existing investors Sevin Rosen Funds, Ventures West and WRF Capital. Alder's Series C financing closed in December 2007 , with a $\$ 40$ million round led by Delphi Ventures of Menlo Park, Calif. and TPG Biotech of San Francisco.

Early on, we made it a priority to find investors that were aligned with our long-term goals as an organization. Finding the correct venture capitalist (VC) for your company is crucial to your eventual success because it is the only way that you will receive flowing capital for necessary trials. Persistence is key in this step, and you must understand from the beginning that you will need to give presentations to countless VCs before finding a group that will be the correct fit.

If you are interested in building your company for the long haul, make sure to find a VC that has a track record of being a company builder. These are classical investors who choose to finance people and ideas over long periods of time. Other VCs will focus more on short-term turnaround and near-term points of liquidity.

Every VC will tell you how to proceed based on its outlook, but at some point you have to start believing in your company and your plan for going forward. VC firms have different needs and strategies. If you listen to each group and change your business plan every time, you will lose focus. Use their advice to sharpen the message but stay true to your own business plan.

high-affinity antibodies, allowed us to get our proof of concept in patients in months instead of years.

That was key, because a common challenge as a startup is understanding that you no longer have the time to spend years identifying new targets and validating them through genetics and genomics as you might have had in your big pharma job. Those efforts would add a tremendous amount of time and risk to a small company's development, which is ultimately detrimental.

As a startup, it is important to think about choosing targets that already have been validated and therefore require less risk to develop. These should be targets that will be attractive to larger companies further along in their pipeline, which will position your company to be the one resolving the larger company's issues with an internally discovered clinical program. This is how you prove to be something of value to big pharma.

\section{Selective hiring}

We were fortunate to start as a group of four people with unique backgrounds and diverse areas of expertise that contributed to the overall organization. Eventually, we added two senior research associates to broaden the skill set of the company. These early hires are key. It is important to find people with whom you have a symbiotic and trustworthy relationship because everybody has to be united behind the common goal. This may be a big change for you if you've come from a major drug developer where employees often are chasing many goals at the same time. It was our persistence and camaraderie that got us through the first 18 months before we landed our Series A funding-salaries are often tight and hours are long in the early days of any company. That's especially true in biotech, so find team members that can get fully behind your vision.

We also knew that we would need a strong legal team if we were to be successful. When building a company, you'll need the correct legal foundations in place from the very beginning. This can be overlooked by new entrepreneurs who are focused entirely on the science, and it's not something any of us had experience with when working at Celltech.

It is important to find an intellectual property attorney who is very knowledgeable in your specific space, not just in the industry. This will allow the attorney to ensure that patents are issued correctly and that you have obtained freedom to operate-a crucial step on the road to success for biotechs.

Most venture capitalists (VCs) will have intellectual property attorneys to bring into the operation, but you should try to have your own as well if it is in your budget. In addition, find a corporate attorney who has experience with small startup companies. The first steps in structuring the corporation and its ownership are the base upon which everything else is built, so poor choices can result in serious repercussions down the line. A first-rate corporate attorney may also have connections in the venture investor space and may be able to provide valuable introductions along the way.

We found our corporate attorney, Sonya Erikson, through Venture Law Group. She helped us put legal foundations in place to build our company the right way. These were things we never had to think about at our old jobs, but if you're launching a company, you'll need representation.

\section{Money, money, money}

Today, it is very difficult to find initial investors purely along venture lines, which is why we suggest pursuing angel investors and available grants. These alternative sources for capital are very helpful to get things going and generate preclinical data.

Our first capital came from Department of Defense grants, because the department was interested in our ability to make antibodies quickly in yeast. They put out a call for proposals on methodologies for making antidotes to biological warfare agents, and we were awarded a grant and raised our first $\$ 100,000$ as a company. The advantage of grants is that they are non-dilutive and do not set a valuation, which is helpful when you do begin getting venture funding. You won't need to convince anyone of your new, higher valuation. The grant meant we could finally pay our scientists, but we knew that we needed to attract venture funding.

Finding investors is a long and grueling process for any startup, but a necessary step all the same. We were fortunate to have a local biotech entrepreneur and successful CEO make our introductions to the VCs for us. Being active in the local biotech community in the early days of a company is important because it helps build relationships that generate these introductions. When raising money, broader is better-most of the time you will meet with people who are not interested, so we met with anyone who would listen to our story. At the same time, don't be afraid to be selective with the VCs that you identify. Just as team members need to get behind the big picture of the company, VCs must also share this vision to keep things running smoothly. Getting a venture group to say "yes" can be as much about timing as their interest in the science and may depend on the stage of their current fund and the venture group's goals.

It took Alder awhile to find the right investors (Box 1). Because of the fact that VCs never say no, there can be many follow-on meetings. This can easily become a never-ending cycle. 
What can be helpful is having an interested VC or CEO who knows about your quest make a call for you and get straight feedback from anyone who's turned you away. This will help focus your efforts.

Another excellent source for funding is corporate venture funds (for example, SR One from GlaxoSmithKline, Novartis Venture Funds, Biogen Idec New Ventures and Takeda Research Investment). Once you have a lead investor, these groups usually participate without a board seat and are good sources for future partnering.

\section{Small bites}

Another challenge faced by those moving into biotech from pharma is knowing how much venture capital funding to take up front. In the early days of a company, VCs have the ability to be very flexible about valuation, often to the company's detriment. The value set when the Series A financing is completed can sometimes come in low and impact how the company is valued in the future. As a result, it is important to be very cautious at this stage. Be sure to seek advice from entrepreneurs that have gone through venture capital financings before. We learned many things from people who were willing to share their past experiences with valuation, and we appreciated this advice, especially given our ongoing transition from working with a major drug developer to being entrepreneurs.

In addition, it is tempting to take a large amount of money up front. After all, things will be tight early on and the larger numbers seem appealing. However, taking an excessive amount of money for Series A will dilute the ownership, and that means it lessens your return as a founder. Focus on taking just enough to fund value creation over the next two years. Choosing to do a smaller financing round can put you at risk, but the advantage comes in building value and reaping the benefits of increased value in later rounds.

One of our initial advisors told us, "The first million dollars will be the hardest dollars you will ever raise." This statement rang true because we were forced to raise money with almost no data and a limited track record. The reason we were able to overcome this hurdle was our drive to continually demonstrate progress. Even with limited resources, we were able to keep showing results at each subsequent meeting. This principle has continued through all our financings. Once you can demonstrate results and meet milestones, you gain credibility. It is this factor that attracts investors.

\section{Conclusions}

If starting a new company after leaving a large organization seems challenging to you, that's because it is. Identifying a unique, high value-generating area to research and building an entire organization takes considerable time and effort. It is a different mentality for the entire team to be united to move things forward and avoid the cliff looming in the distance. But the rewards are also substantial, allowing you and your team to pursue the science you find most interesting and promising. At the same time, you may even end up making some money-more than you would have had in your 'safe' job at a big pharma company.
To discuss the contents of this article, join the Bioentrepreneur forum on Nature Network: http://network.nature.com/groups/bioentrepreneur/forum/topics 